\title{
The Reproductive Capacity of the Apple Leaf-Curling Aphids (Myzus malisuctus Matsumura) Reared on Gibberellin- Treated Apple Trees ${ }^{1,2}$
}

\author{
Syôzô HuKusima \\ Laboratory of Entomology, Faculty of Agriculture, Gifu University, Kagamihara, Gifu
}

Generally it has been known that controls of the crop pests were based mainly upon the utilization of ( 1 ) natural enemies, (2) plant nutrition caused by various cultural practices, and ( 3 ) chemicals effective for pest infestations. In connection with the above conception, especially with the second method correlations between mite and aphid reproductions and mineral composition of soil and plant tissue have hitherto been studied by many workers (ARANT and Jones, 1951; BARKER and Tauber, 1951, 1951 a, 1954; Davidson, 1925; Evans, 1938; GARMAN and KENNEDy, 1949; Hamstead, 1957, Haseman, 1946; Hukusima, 1958; Maltais, 1951; Rodriguez, 1951, 1951 a, 1958; Taylor, Apple and Berger, 1952). In addition to these, from a general interest in the effects of growth regulators on plants, considerable studies of gibberellic acid have also been carried out by some workers (EICHMEIER and Guyer, 1960; Rodriguez and CAMPBell, 1961) in the area of orchard mites and their relationship with the host. As the result of these studies, some information of ecological interest has been demonstrated. One of the findings was a significant reduction in phytophagous mite population which was caused by the gibberellic acid treatments to the host plants, as would be expected, and at the same time a marked increase of plant height over the check was shown.
At this time, as the cause of the phenomenon it was concluded that the reduction in mite population on the gibberellic acidtreated plants was due to some nutritional factors rather than plant growth. Consequently it has become evident that the influence of the nutrition of the host plant might be an important aspect in understanding of the mite population development in the crop field.

On this evidence, the purpose of this work was to determine if aphid development with gibberellin applications would be affected in the same way as was the case of the mite reproduction.

\section{MATERIALS AND METHODS}

Present work was conducted during the apple growing season from late May to late September, 1962, in a net house of fluctuating temperature and fluctuating light conditions. The seedlings of the Ralls Janet apple variety were set in autumn of 1961 in clay pots of $24 \mathrm{~cm}$ in diameter filled with loam with one seedling per pot. In the beginning of the experiment on May 28, 1962, 12 pots were selected at random and ten apterous viviparous females of the apple leaf-curling aphid, Myzus malisuctus Matsumura, were set on the lower part of each seedling. In this way, aphid population in each treated plot was consisted of the progeny developed

Studies on the Insect Association in Crop Field XXXI

2 Contribution No. 29 from the Laboratory of Entomology, Faculty of Agriculture, Gifu University.

(Received for publication, August 8, 1963) 
from these females throughout the season. The seedlings were then treated to be run off by gibberellin aerosols which were equivalent to 10,50 and 100 parts per million aqueous solutions at weekly intervals until late September. Thus, the vegetative growth by extended height, number of leaves and aphid reproduction on plants in each treatment which included three replicates were measured respectively at the same intervals. In this case the readings of the two-spotted spider mites, Tetranychus telarius Linné, were depend on the progeny of natural reproduction.

To ascertain the nutritional value of apple trees, the analyses of reducing and total sugars were made separately on the foliages of each treated tree. About five grams of dried apple foliage were treated with following procedures as shown in Figure 1 for the preparation of sugar
Dried apple foliage

-Extraction with $90 \%$ ethanol

Ethanol extract

- Ethanol evaporation and filtration of residue

Filtrate

$$
\begin{aligned}
& -10 \% 3 \mathrm{~Pb}\left(\mathrm{CH}_{3} \mathrm{COO}\right)_{2} \cdot 2 \mathrm{PbO} \\
& - \text { Centrifugation }
\end{aligned}
$$

Supernatant

- Saturated solution of $\mathrm{C}_{2} \mathrm{O}_{4} \mathrm{H}_{2}$

Sugar solution

Fig. 1. Preparation of sugar solution.

solutions. The sugar solution thus obtained was used for the quantitative determination of glucose in respective treatment plots with the photoelectric colorimeter.

\section{RESULTS}

As shown in Figures 2 and 3, for several days after gibberellin treatment, there was no significant difference in plant growth

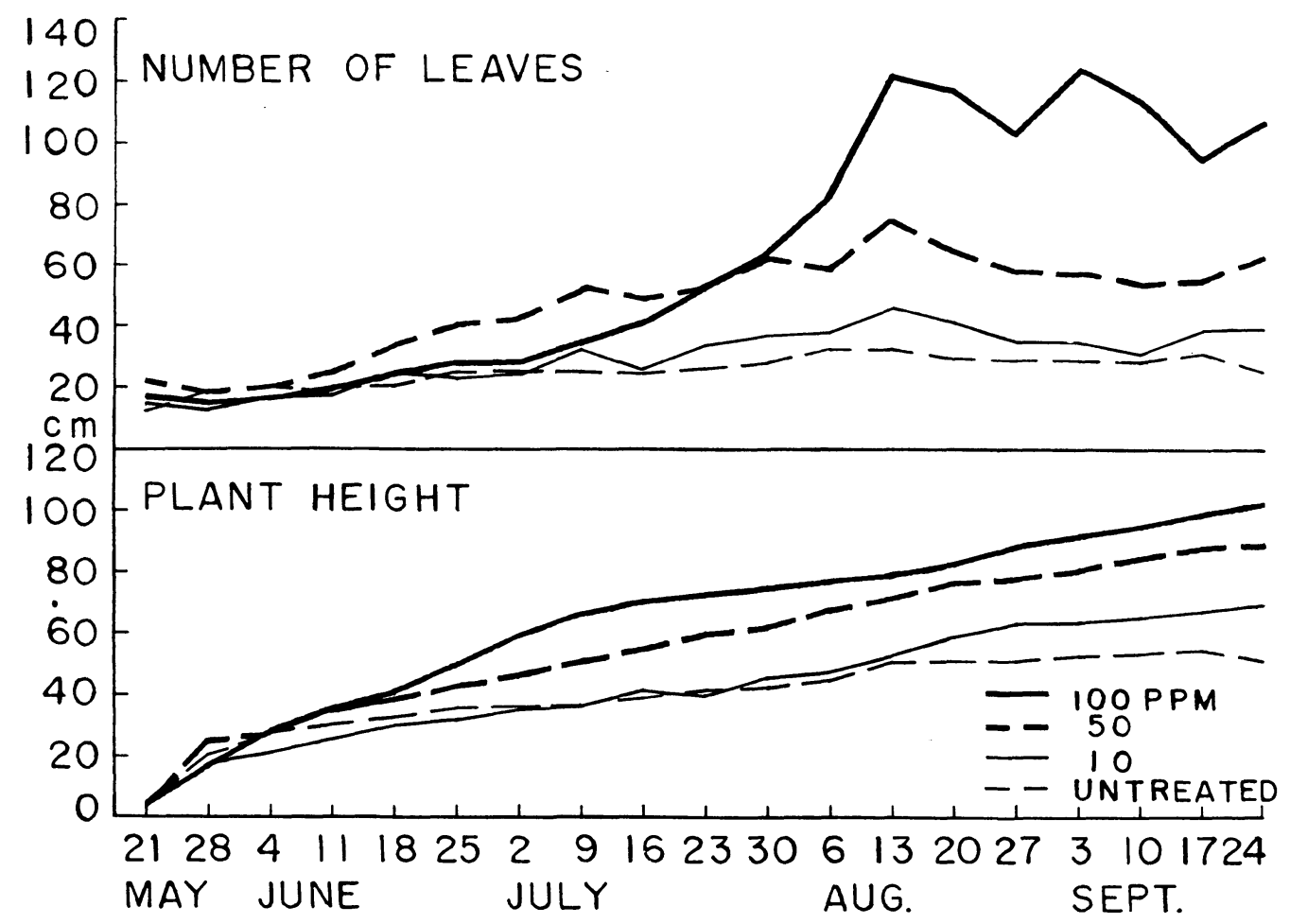

Fig. 2. Effect of gibberellin sprays on growth of plant height and increase of number of leaves in Ralls Janet apple trees. Both readings are represented as average measurements of three seedlings in each treatment. 


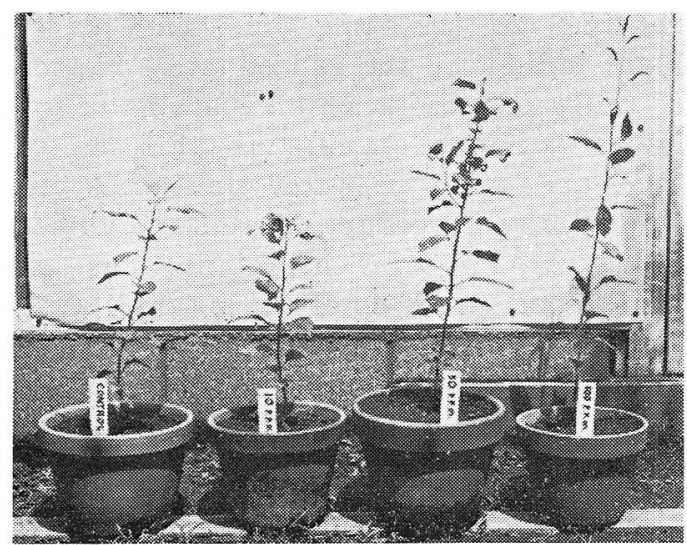

Fig. 3. Symptoms of apple seedlings infested by apple leaf-curling aphids under different gibberellin treatments on July 17,1962 .

among the plots tested, but afterwards higher treatments definitely resulted in the growth significantly greater than the check, and this situation thus lasted till recording was ended. As to the number of plant leaves, although the same trend with the plant height should not be clearly expected, a similar tendency was observed toward latter part of the season.

The effect of gibberellin sprays at weekly intervals on the aphid reproduction in the presence of phytophagous mites is given in Table 1. From the carry-over reproduction during five months, it will be noted that the lowest treatment of gibberellin (e. g., 10 p. p. m.) not only raised the development of Myzus aphids to rather the same extent with that of the check, but also often yielded far higher level of population than that of the check through the test. However, of the 10,50 and 100 p. p. m. treatments, application of higher gibberellic acid decreased, according to that order of capacity, the reproduction of aphids as was evident in successive march of population on apple trees. As shown in Table 1 , in a subsidiary estimate of the population growth in Tetranychus

Table 1. Effect of gibberellin sprays on reproductions of aphid, Myzus malisuctus Matsumura, and mite, Tetranychus telarius Linné, reared on Ralls Janet apple trees.

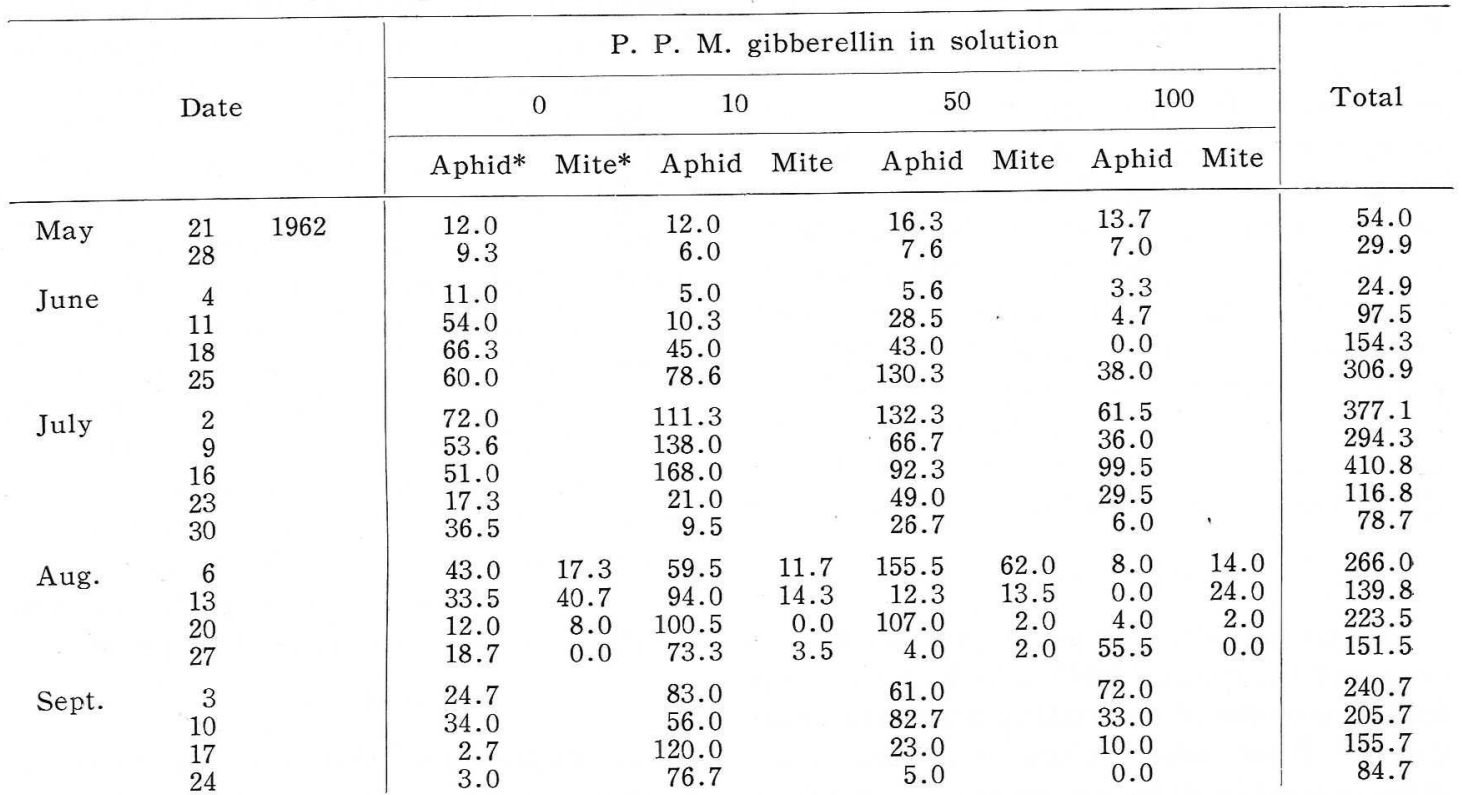

Among blocks

Aphid: $\mathrm{F}=7.34 * *>\mathrm{F}^{3}{ }_{54}(0.01)=4.3$

Mite: $\mathrm{F}=15.17^{* *}>\mathrm{F}^{3}{ }_{12}(0.01)=5.95$

* Both species are expressed as the average readings on three seedlings in each treatment, and aphid populations depend on progeny resulted from ten apterous viviparous females which were set on lower part of each seedling. 
mites, it will further be noticed that there was general indication of the reduction to a considerable decrease of population level of the mites when the higher rates of gibberellin were applied.

Aside from above aspects, on the basis of determination of reducing or total sugars in apple foliages, it is hard to mark the clear-cut demarcation among the test projects, but the general tendency of the sugar contents caused by these applications

Table 2. Effect of gibberellin acid on per cent sugar of apple foliages.

\begin{tabular}{c|cc}
\hline \multirow{2}{*}{$\begin{array}{c}\text { P. P. M. gibberellin } \\
\text { in solution }\end{array}$} & \multicolumn{2}{|c}{ Sugar $(\%)^{*}$} \\
\cline { 2 - 3 } & Reducing & Total \\
\hline 0 & 1.8 & 2.2 \\
10 & 1.1 & 2.0 \\
50 & 1.8 & 2.5 \\
100 & 1.6 & 3.4
\end{tabular}

* Measurements are the average readings based on two replications on November 27, 1962.

of gibberellic acid may be seen in Table 2 . It may, therefore, safely be judged that, as a rule, the higher the gibberellin treatment was, the less remarkable was the carry-over effect of the reducing sugar, while no consistent effect was detectable in total sugar; in other words, the effects of the total sugars considerably varied with different treatments. This effect on reducing sugars is probably consistent with the findings already revealed by Rodriguez, Maynard and Smith Jr. (1960) in Tetranychus mite fashion on Black Valentine beans and Clark soybeans.

\section{DISCUSSION}

According to the experiments by RoDRIGUEZ and CAMPBELL (1961) which were done for the purpose of evaluating both reproduction of Tetranychus mites resulting from different gibberellin treatments and plant height caused by quite the same treatments, the gibberellic acid applications all increased plant height of beans and cottons and the branches of apple trees signifi- cantly. At the same time, such a treatment influenced the reproductive capacity of mites on plants which was significantly lower than the check. In this context, the correlation between the two-spotted spider mite reproduction and the gibberellin treatment of bean plants has been also ascertained by EICHMEIR and GUYER (1960). Thus, it was positively pointed out that the reduction in mite populations on gibberellic-acid-treated plants was due to some other factors rather than plant growth itself.

Coming back again to the present article, the reproductive capacity of aphids and mites on apple foliages was inhibited by the use of higher level of gibberellic acid solution as was stated previously by the senior authors on bean or orchard mites.

As one possible cause of this situation, Rodriguez, MAYNARD and SMith JR. (1960) gave conclusive evidence that the Tetranychus mite reproduction was correlated positively with reducing sugar and nitrogen, and in some cases with total sugar, and negatively with phosphorus, potassium of foliages. The analytical determination obtained in this chapter was not taken in sufficient details to draw a firm conclusion, but there is a widespread interest that the reducing sugar was relatively decreased at the higher rates of gibberellin treatment. Therefore, it is probably safe to say that there is an optimum level of reducing or total sugars for the aphid development, just as there is an optimum level for other nutrients as was recently referred to by RodRIGUez and CAMPBeli. (1961) on the mite reproduction. If this interpretation was accepted as correct, such a situation seems to be worth studying further for the control against aphids.

\section{SUMMARY}

The experiment was undertaken to determine whether or not reproduction of the apple leaf-curling aphids was affected by the use of gibberellic acid. For this purpose of the study four treatments of gibbereliin were applied on apple seedlings 
under fluctuating temperature and fluctuating light conditions in a net house. From the over-all arguments, it is concluded that higher level of gibberellic acid was requierd in order to effect a significant reduction in aphid populations. Beyond any doubt, such differences will appear on the differences of the nutritional basis rather than on direct plant growth. In this respect, analyses of reducing and total sugars of apple foliages proved that the reducing sugar was lowered down in the treated plants despite no apparent effect was detected in total sugar. This close linkage between the aphid development and plant nutrition is probably due to the gibberellin application.

\section{REFERENCES}

Arant, F. and C. M. Jones (1951) Jour. Econ. Ent. 44: 121 .

BArker, J. S. and O. E. TAuber (1951) Jour. Econ. Ent. 44: 125.

Barker, J. S. and O. E. TAuber (1951a) Jour. Econ. Ent. 44: 1010 1012.

Barker, J. S. and O. E. TAuber (1954) Jour. Econ. Ent. 47: 113 116.
Davidson, J. (1925) Ann. Appl. Biol. 12: 472 507.

Eichmeier, J. and G. Guyer (1960) Jour. Econ. Ent. 53: 661 664.

Evans, A. C. (1938) Ann. Appl. Biol. 25: 558 572.

Garman, P. and B. H. Kennedy (1949) Jour. Econ. Ent. 42: $157 \sim 158$.

Hamstead, E. O. (1957) Jour. Econ. Ent. 50: 109 110.

Haseman, L. (1946) Jour. Econ. Ent. 39: 8 11. Hunusima, S. (1958) Bull. Fac. Agric. Hirosaki Univ. 4: 72〜 79.

Maltais, J. B. (1951) Canadian Ent. 83: 29 33. Rodriguez, J. G. (1951) Proc. 6 th Annu. Meeting North Central States Branch AAEE: 112 113.

Rodriguez, J. G. (1951a) Ann. Ent. Soc. Amer. 44: $511 \sim 526$.

Rodriguez, J. G. (1958) Jour. Econ. Ent. 51: 369 $\sim 373$.

Rodriguez, J. G., D. E. Maynard and W. T. SMITh JR. (1960) Jour. Econ. Ent. 53: 491 495.

Rodriguez, J. G. and J. M. CAmpbell (1961) Jour. Econ. Ent. 54: 984 987.

Taylor, L. F., J. W. Apple and K. C. Berger (1952) Jour. Econ. Ent. 45: 843 848.

摘

要

リンゴコブァブラムシの生殖力に执よばすジベレリンの影響

\author{
福島正 三 \\ 岥阜大学農学部昆虫学研究室
}

ジベレリン処理リンゴ樹上のリンゴコブアブラムシ個 体群が処理濃度の相違によって増減する程度をしらべた ところ, 高濃度処理樹上のものが低濃度におけるよりも 減少することがわかった。個体数は少ないが，同様な傾 向はナミハダニの場合にもみられる。このようなアブラ
ムシの増減とリンゴ葉の還元糖および全糖の消長との関 係において，全糖との間には一定の傾向をみとめがたい が，還元糖の減少がアブラムシ個体群を低下させる一因 と考えられた。 